Research Article

\title{
Ovipositional preference of potato tuber moth and its damage to different genotypes of potato in free choice condition
}

\author{
Sunil Aryal ${ }^{1 *}$ and Resona Simkhada ${ }^{1}$ \\ ${ }^{1}$ Nepal Agricultural Research Council, National Entomology Research Centre, \\ Khumaltar, Lalitpur, Nepal. \\ *Correspondence: sunilaryal2005@ gmail.com; \\ ORCID: https://orcid.org/0000-0002-5993-4209 \\ Received: July 20, 2020; Accepted: October 15, 2020; Published: October 30, 2020
}

(C) Copyright: Aryal and Simkhada (2020)

(c) (1) (9)

This work is licensed under a Creative Commons Attribution-Non Commercial 4.0 International License.

\begin{abstract}
Potato tuber moth is a serious pests of potato which cause qualitative as well as quantitative loss on tubers at stores. Major control mechanism is to use chemical pesticide but this pose great hazard risk to the growers and consumers. Therefore this study evaluated tubers of ten potato genotypes viz. CIP 394600.52, CIP 393371.164, Khumal Ujjawal, PRP 296667.2, CIP 393385.39, CIP 395112.32, PRP 226567.2, PRP 0165667.6, CIP 393371.159, and Khumal Upahar against potato tuber moths for their ovipositional preferences and damage potential with nine replication in the laboratory. Number of deposited eggs for four days at eye and on the tubers skin, number of tunnel and tunnel length was measured. Least percentage of egg laid eye was least in genotype CIP 394600.52, CIP 393371.164 and variety Khumal Ujjawal respectively. The least number of total eggs laid on eyes was on genotype CIP 394600.52 (2.33 21.00$)$ followed by variety Khumal Ujjwal (6.00 \pm 2.45$)$. Although genotype CIP 393385.39 was among the most preferred genotype for oviposition, average number of tunnels and average total tunnel length remained very low. Factors such as physical, nutritional, chemical or genetical which may be involved inducing resistance mechanism thus should also be studied and verified.
\end{abstract}

Keywords: Damage, genotype, oviposition, potato tuber, Potato tuber moth

Correct citation: Aryal, S., \& Simkhada, R. (2020). Ovipositional preference of potato tuber moth and its damage to different genotypes of potato in free choice condition. Journal of Agriculture and Natural Resources, 3(2), 104-117.

DOI: https://doi.org/10.3126/janr.v3i2.32494

\section{INTRODUCTION}

Potato is one of the important vegetable crops in Nepal. It is used as subsidiary food as part of vegetables in Terai region, whereas as staple food in Hill and Mountain Regions of Nepal (Subedi et al., 2019). It is commercial non-cereal produce of Nepal and an important source of income for the farmers (Upadhyay et al., 2020a). Recently the area, production and productivity of potato were recorded throughout Nepal were 195,173 ha, 2,881,829 tons and of $14.7 \mathrm{t} / \mathrm{ha}$, respectively during the year 2017/18 (MoALD, 2019). During the seasonal food shortage and depletion of grains, potato serves both as reliable food and income security to farmers (Sisay \& Ibrahim, 2012). If the potato seed are not protected, considerable amount of potato is lost in field as well as during post-harvest handling and storage (Sisay \& Ibrahim, 2012). Post-harvest losses were considerably high in South-Asian countries. India and Bangladesh incurred 24 and 20\% losses while in Nepal it was as high as 25\% (Prasad et al., 1989; Karki, 2002; Satter et al., 2002). Losses in storage is caused by one 
of the notorious pests potato tuber moth, Phthorimaea operculella (Zeller) (Lepidoptera: Gelechiidae), which is the major host of potato (Kroschel \& Koch, 1994) along with other various solanaceous crops like tomato (Aryal \& Jung, 2019), eggplant and others (Das \& Raman, 1994). PTM is now distributed in approximately 110 countries due to various factors like change in climate, improper quarantine systems (Sporleder, 2008; Kroschel et al., 2013) and climate suitability combined with host plant availability (Jung et al., 2020). PTM was introduced in Nepal when potato varieties were imported from India to Kathmandu for adaptive research under Indian Aid Mission program during early sixties (Joshi, 2004). PTM has been reported in Nepal from more than 15 districts (Aryal \& Jung, 2015a) including Jumla (Tiwari et al., 2006). The most important damage is to tubers, also a food source for the larvae, especially exposed tubers, or those within centimeters of the soil surface. Farmer's general practice to keep on using infested seed potatoes is the major reason behind build-up of potato tuber moth population (Kroschel \& Koch, 1994) in storage facilities. PTM damage under field and storage condition ranged from 20-30\% in normal condition whereas harvesting the potato at peak infestation period along with improper storing condition leads to 25 to $100 \%$ damage (Nirual, 1960; CIP, 1988; Joshi, 1989; Sileshi \& Teriessa, 2001). Rondon and Gao (2018) reviewed the losses in storage and where PTM inflicted 1-100\% damage to tubers of various regions. Larvae can infest tubers when foliage is vine killed or desiccated right before harvest (Gao, 2015). The delaying in harvesting might result in heavily damaged tubers in the field condition. It causes damage both by making tunnels and feeding that mostly leads to rotting by bacteria/fungi infestation, making it unfit for consumption (Alvarez et al., 2005).

To control this pest, farmers use insecticides that cause health threats to themselves, their families, consumers and the environment. Farmers in developing countries continue to use toxic pesticide on stored potato in their household which often exposes family members to pesticide hazards. An integrated pest management (IPM) strategy which utilizes natural enemies and other alternative measures play significant roles in protection of PTM (Giri et al., 2013), for which Aryal and Jung (2015b) describes various control measure including host plant resistance which minimizes the negative effects of chemical pesticides and also provide sustainable control. Several previous studies have performed to know the resistance of the several potato varieties (Foot, 1976; Raman \& Palacios, 1882; Gyawali, 1989; Arnone et al., 1996; Gurr \& Symington, 1998; Smith, 2005; Dogramaci \& Tingey, 2009; Horgan et al., 2009; Rondon et al., 2009 2013) and the egg laying preferences on leaves and tubers (Golizadeh \& Esmaeili, 2012). Therefore this experiment was conducted with aim to determine egg laying preferences and damage induced to potato tubers of different potato genotypes against PTM infestation during storage condition.

\section{METHODOLOGY}

\section{Insect rearing}

Potato tuber moth (PTM) used in the experiment was maintained at the Laboratory of National Entomology Research Center, Khumaltar, Lalitpur. The potato tubers were placed in container boxes with fine sterilized sand at the bottom and incubated at $25 \pm 1^{\circ} \mathrm{C}$ with relative humidity $(\mathrm{RH}) 65 \pm 5 \%$. Dry sand served as pupation medium. When the larvae had completed the larval stage, the pupae (with their cocoons) were harvested through sieving. Cocoons were removed and pupae surface-sterilized by washing them in a sodium hypochlorite solution (0.3\%) (Sporleder et al., 2004). The collected pupae were air-dried and placed in a cylindrical plastic container $(\varnothing 12 \mathrm{~cm} \times 12 \mathrm{~cm}$ depth), which was covered with a 
mesh cloth. After adult emergence, a filter paper was placed on the mesh cloth as oviposition medium. Adults were fed with 5\% sugar solution, which was dropped on the edges of the filter paper. Eggs were let to hatch and used for experiments or for further rearing. In this way rearing cycle was continued to multiply the PTM for providing sufficient eggs for experiments (Maharjan \& Jung, 2011; Aryal \& Jung, 2018; Dekebo et al., 2019a).

\section{Potato cultivars}

Evaluation of the susceptibility of ten potato genotypes, obtained from National Potato Research Program (NPRP), to potato tuber moth infestation was done in laboratory through the study of its ovipositional preference and damage potential using choice test. Seeds obtained from NPRP were planted and tubers obtained were used for the experiments. Ten tested potato varieties were CIP 394600.52, CIP 393371.164, Khumal Ujjawal, PRP 296667.2, CIP 393385.39, CIP 395112.32, PRP 226567.2, PRP 0165667.6, CIP 393371.159, and Khumal Upahar (Table 1). They were planted at NERC field during 2019 and experiments were conducted from the tubers harvested from the field.

\section{Egg laying preferences and damage susceptibility}

A plastic box (29.5 X $22.5 \mathrm{X} 13.5 \mathrm{~cm})$ (Figure 1A) was taken and ten potato tuber each from ten genotypes was arranged inside the box randomly in CRD design (Figure 1B) under laboratory condition having $26.7^{\circ} \mathrm{C}\left( \pm 0.32^{\circ} \mathrm{C}\right)$ and $75 \%$ R.H $( \pm 10 \%)$ throughout study period. Five pairs of unmated male and female potato tuber moth were introduced inside the box through the small inlet which was clogged with cotton roll afterwards. Each box was replicated nine times. This experiment was conducted without supplying any food materials to the adult moths. Number of deposited eggs for four days at eye and outside eye of the tubers on skin was counted and cumulative number of egg laid was recorded up to four days. The eggs were allowed to hatch and damages were assessed for every genotype on every replication after pupation. Number of tunnel and tunnel length made by PTM larvae were measured with vernier caliper. Length of many tunnels in a tuber of each genotypes were summed up and mean were analyzed. The number of eggs laid inside the surface was not counted.
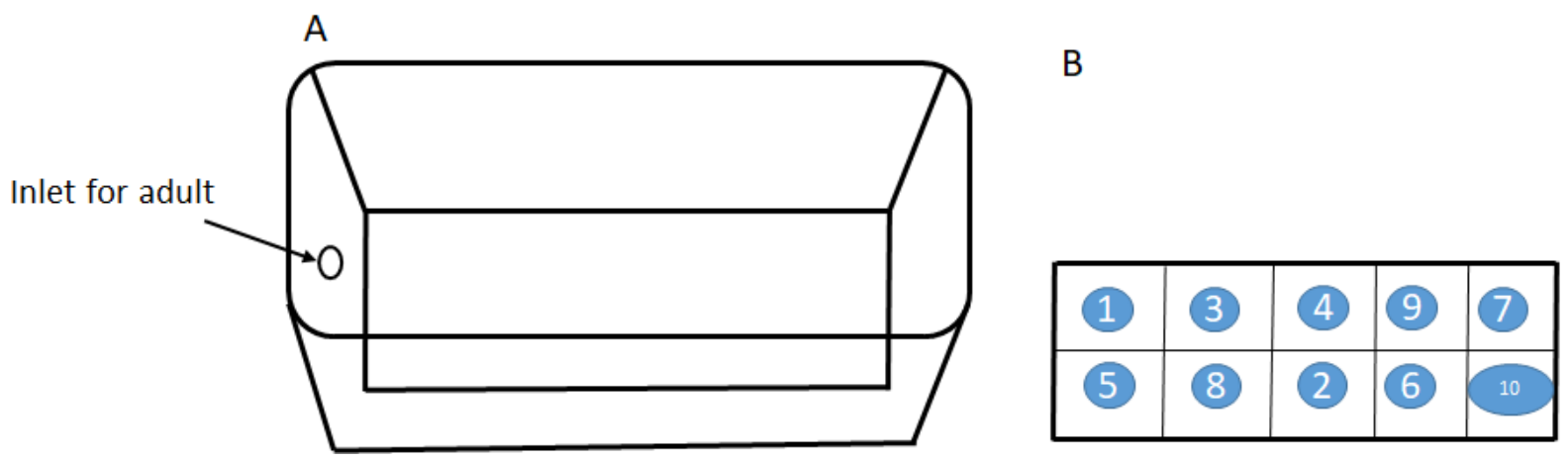

Figure 1: Unit of experiment block. A- Design of box for the experiments. B- Base of the box with randomization for the placement of tuber of potato genotype. Such 9 boxes $(9$ replication) used for the experiments in choice test. 


\section{Statistical analysis}

Percent eye with egg, no of egg on eye, on skin outside eye and total egg, Number of tunnel and tunnel length was subjected to one way ANOVA. Days of egg laying preferences on different genotypes were subjected to two way ANOVA. Correlation was performed to evaluate relationship between percent eye with total no of egg laid, no of tunnel and length of tunnel, and eye depth and egg laid on eye. Mean were separated using Tukey's Post hoc test at 0.05 level. Data were square root transferred before analysis. Date were analyzed using SPSS 16 software (SPSS inc. 2016).

\section{RESULTS}

\section{Characteristics of potato genotypes}

Average number of eyes and eyes depth along with surface area and color are presented in Table 1. In order to evaluate the susceptibility of potato tuber varieties to PTM, certain tuber characters such as number of eyes, eye depth, surface area and color was determined under laboratory conditions. Further, these characters could also be associated with ovipositional and tunneling preference of the insect. Genotype CIP 393385.39 was found to be a potato tuber genotype with both highest number of eyes $(8.80 \pm 0.72)$ and eye depth $(2.97 \pm 0.51 \mathrm{~mm})$ respectively whereas genotype CIP 395112.32 showed least number of eyes $(6.20 \pm 0.60)$ (Table 1).

Table 1. Genotypes evaluated for PTM susceptibility their characteristics

\begin{tabular}{llllll}
\hline SN & Genotypes & $\begin{array}{l}\text { Average surface } \\
\text { area }\left(\mathrm{cm}^{2}\right)\end{array}$ & $\begin{array}{l}\text { Average no. of } \\
\text { eyes }\end{array}$ & $\begin{array}{l}\text { Average eye } \\
\text { depth }(\mathrm{mm})\end{array}$ & Colour \\
\hline 1 & CIP 394600.52 & $25.07( \pm 1.79)$ & $7.40 \pm(0.65)$ & $2.15 \pm(0.18)$ & White \\
2 & CIP 393371.164 & $20.66( \pm 1.79)$ & $8.00 \pm(0.51)$ & $2.34 \pm(0.25)$ & White \\
3 & Khumal Ujjawal & $19.57( \pm 0.68)$ & $6.50 \pm(0.44)$ & $2.45 \pm(0.21)$ & White \\
4 & PRP 296667.2 & $18.98( \pm 6.90)$ & $6.40 \pm(0.36)$ & $2.48 \pm(0.17)$ & White \\
5 & CIP 393385.39 & $21.45( \pm 2.10)$ & $8.80 \pm(0.72)$ & $2.97 \pm(0.51)$ & Red \\
6 & CIP 395112.32 & $19.00( \pm 2.18)$ & $6.20 \pm(0.60)$ & $2.25 \pm(0.33)$ & Red \\
7 & PRP 226567.2 & $23.74( \pm 1.44)$ & $7.30 \pm(0.58)$ & $2.42 \pm(0.32)$ & White \\
8 & PRP 0165667.6 & $22.06( \pm 1.72)$ & $7.00 \pm(0.35)$ & $2.18 \pm(0.26)$ & Red \\
9 & CIP 393371.159 & $20.48( \pm 1.39)$ & $7.80 \pm(0.55)$ & $2.34 \pm(0.21)$ & Yellowish \\
10 & Khumal Upahar & $21.67( \pm 1.67)$ & $8.50 \pm(0.50)$ & $2.46 \pm(0.26)$ & White with red eye \\
\hline
\end{tabular}

Numbers in parenthesis indicates standard error $( \pm S E)$

\section{Ovipositional preferences}

Ovipostional preference were not significantly different during first $\left(\mathrm{F}_{9,90}=0.729, \mathrm{P}=0.6814\right)$, second $\left(\mathrm{F}_{9,90}=1.118, \mathrm{P}=0.0 .360\right)$ and third day $\left(\mathrm{F}_{9,90}=1.770, \mathrm{P}=0.087\right)$ while at fourth day $\left(\mathrm{F}_{9}\right.$, $90=2.036, \mathrm{P}=0.046$ ) the egg laying preferences were significantly different among the genotype tested (Table 2). Genotype CIP $393385.39(23.11 \pm 10.95)$ was preferred most to lay egg upon by PTM followed by PRP 296667.2 (16.56 \$5.41) while CIP 394600.52 (2.33 $\pm 1.00)$ was least preferred. Two way analysis of the number of eggs with egg laying days showed that the egg laying preference on genotypes $\left(\left(\mathrm{F}_{9}, 360=5.013, \mathrm{P}=<0.001\right)\right.$ and number of cumulative egg per days $\left(\mathrm{F}_{9}, 360=32.74, \mathrm{P}==<0.001\right)$ were significantly different but the interaction of the genotype with egg per day $\left(\mathrm{F}_{27,360}=0.593, \mathrm{P}=0.948\right)$ was not significantly different (Table 3). 
Table 2: Daily mean cumulative number of egg up to day 4 laid by PTM on different varieties of potato tubers.

\begin{tabular}{lcccc}
\hline Potato Genotypes & \multicolumn{4}{c}{ Cumulative mean egg number laid on tuber $(\mathrm{n}=4)$} \\
\cline { 2 - 5 } & Day1 & Day2 & Day3 & Day4 \\
\hline CIP 394600.52 & $0.67( \pm 0.55)$ & $1.78( \pm 1.05)$ & $2.00( \pm 0.96)$ & $2.33( \pm 1.00) \mathrm{b}$ \\
CIP 393371.164 & $1.78( \pm 1.30)$ & $4.33( \pm 2.27)$ & $7.33( \pm 3.34)$ & $8.78( \pm 3.41) \mathrm{ab}$ \\
Khumal Ujjawal & $0.56( \pm 0.44)$ & $1.56( \pm 0.67)$ & $3.44( \pm 1.26)$ & $6.11( \pm 2.52) \mathrm{ab}$ \\
PRP 296667.2 & $1.67( \pm 0.69)$ & $5.89( \pm 1.63)$ & $15.22( \pm 6.55)$ & $16.56( \pm 5.41) \mathrm{ab}$ \\
CIP 393385.39 & $1.56( \pm 0.77)$ & $7.00( \pm 2.11)$ & $17.44( \pm 6.42)$ & $23.11( \pm 10.95) \mathrm{a}$ \\
CIP 395112.32 & $1.44( \pm 0.75)$ & $3.67( \pm 1.20)$ & $13.67( \pm 5.35)$ & $13.44( \pm 3.58) \mathrm{ab}$ \\
PRP 226567.2 & $1.78( \pm 1.06)$ & $5.56( \pm 3.85)$ & $12.00( \pm 7.95)$ & $10.33( \pm 5.81) \mathrm{ab}$ \\
PRP 0165667.6 & $2.56( \pm 0.84)$ & $3.00( \pm 1.00)$ & $10.78( \pm 2.25)$ & $15.22( \pm 3.84) \mathrm{ab}$ \\
CIP 393371.159 & $0.78( \pm 0.36)$ & $3.00( \pm 1.34)$ & $9.89( \pm 4.90)$ & $13.89( \pm 6.97) \mathrm{ab}$ \\
Khumal Upahar & $2.11( \pm 1.03)$ & $4.78( \pm 2.00)$ & $8.56( \pm 2.93)$ & $10.11( \pm 3.23) \mathrm{ab}$
\end{tabular}

Mean indicated by same letter are not significantly different $(\alpha=0.05 \%)$. Data analysis done after data are transformed to square root $\{$ sqrt $(x+0.5)\}$. Numbers in parenthesis indicates standard error $( \pm S E)$

Table 3: Two way combine analysis of potato genotypes and days for the cumulative number of eggs laid by PTM on tubers

\begin{tabular}{lll}
\hline S.N & Variety & Mean number of egg $(\mathrm{n}=36)$ \\
\hline 1 & CIP 394600.52 & $1.69( \pm 2.04) \mathrm{c}$ \\
2 & CIP 393371.164 & $5.56( \pm 3.46) \mathrm{abc}$ \\
3 & Khumal Ujjawal & $2.92( \pm 2.73) \mathrm{ab}$ \\
4 & PRP 296667.2 & $9.83( \pm 4.39) \mathrm{c}$ \\
5 & CIP 393385.39 & $12.28( \pm 5.74) \mathrm{c}$ \\
6 & CIP 395112.32 & $8.06( \pm 3.82) \mathrm{bc}$ \\
7 & PRP 226567.2 & $7.42( \pm 5.71) \mathrm{abc}$ \\
8 & PRP 0165667.6 & $7.89( \pm 3.01) \mathrm{bc}$ \\
9 & CIP 393371.159 & $6.89( \pm 5.06) \mathrm{abc}$ \\
10 & Khumal Upahar & $6.39( \pm 3.01) \mathrm{abc}$ \\
& Genotype & $\mathrm{F}_{9,360}=5.013(\mathrm{P}=<0.001)$ \\
& Day & $\mathrm{F}_{3,360}=32.74(\mathrm{P}=<0.001)$ \\
& Genotypes X Day & $\mathrm{F}_{27,360}=0.593(\mathrm{P}=0.948)$ \\
\hline
\end{tabular}

Mean indicated by same letter are not significantly different $(\alpha=0.05 \%)$. Analysis done after data transformed to square root $\{$ sqrt $(x+0.5)\}$. Numbers in parenthesis indicates standard error $( \pm S E)$ 


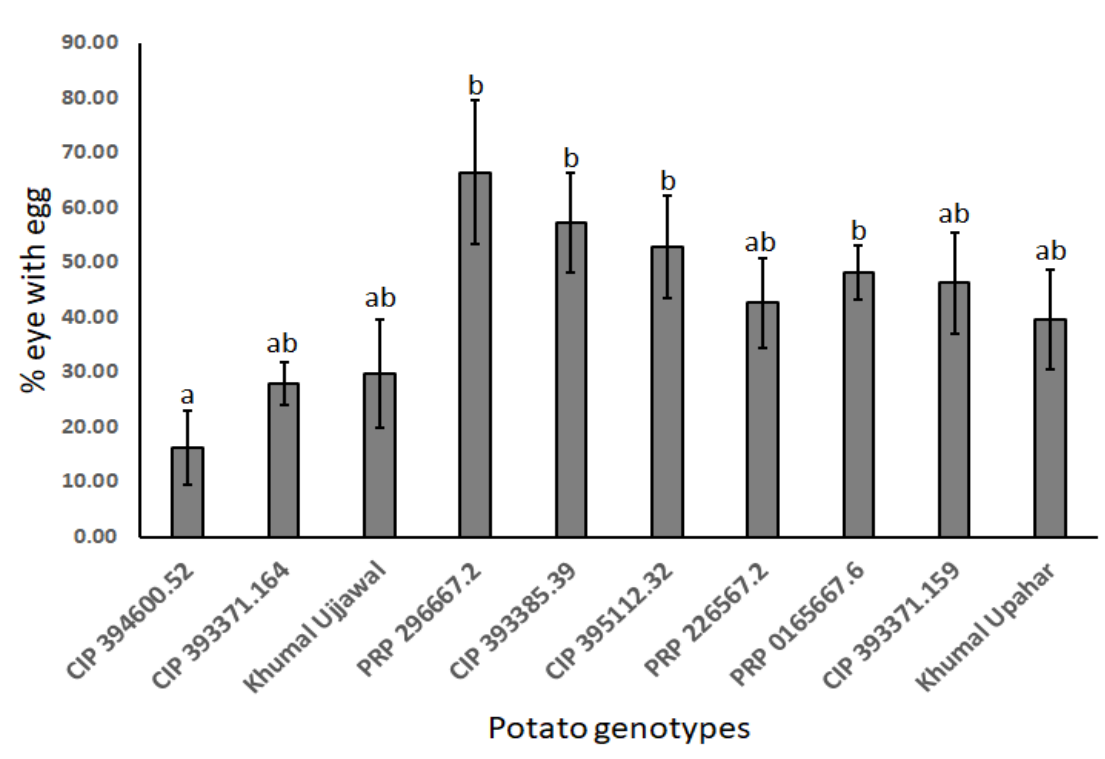

Figure 2: Percent of eye with egg laid by potato tuber moth. Bar represent standard error $( \pm$ SE). Letter above bars indicate mean difference with Tukey's Post hoc at 0.05 level.

Percent eye in the tubers with egg laid by PTM on different genotypes of potato differs significantly $\left(\mathrm{F}_{9,90}=3.55, \mathrm{P}=0.004\right)$. Figure 2 showed the percent of eyes with eggs laid by potato tuber moth (PTM) in choice test. PTM laid eggs on all the tested ten potato genotypes,

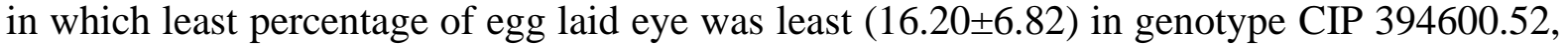
CIP 393371.164 and variety Khumal Ujjawal (29.93 \pm 9.97$)$ respectively (Figure 2).

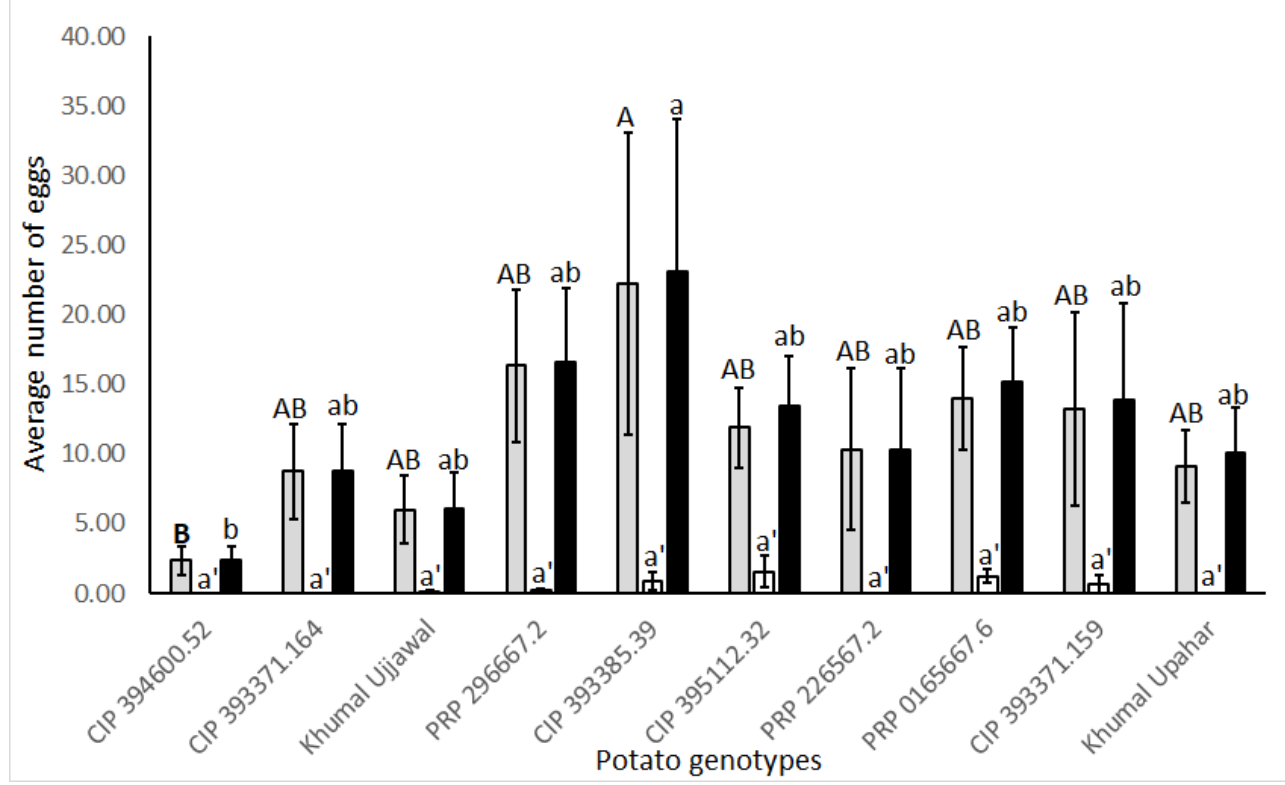

Figure 3: Number of eggs laid by PTM on tubers. Dark bar indicate average number of total egg combine with egg laid on tuber eyes as well as on skin outside eye, grey bar indicate average number of total eggs laid on eyes of the tubers, white bar indicates egg laid outside the eyes in potato tuber surface. Letter above bars indicate mean difference with Tukey's Post hoc at 0.05 level. Bar represents standard errors $( \pm \mathrm{SE})$. 
The highest number of eye with egg $(66.39 \pm 13.08)$ was in genotype PRP 296667.2 followed by CIP 393385.39, CIP 395112.32, PRP 0165667.6, CIP 393371.159, PRP 226567.2 and variety Khumal Upahar respectively.

The chart showed the total number of eggs laid by potato tuber moth (PTM) in tuber eyes and the egg laid outside of eyes. The total number of eggs laid outside (on surface other than eye area) was very less in comparison to the total number of eggs laid in eyes and were significantly not varied among the tested genotypes $\left(\mathrm{F}_{9,90}=1.27, \mathrm{P}=0.23\right)$ (Figure 3). PTM laid eggs on eyes of all the tested ten potato genotypes and were also significantly not different among the genotypes $\left(\mathrm{F}_{9,90}=5.40, \mathrm{P}=0.07\right)$ were as total egg laid on eye and outside eye were significantly differ among the genotypes $\left(\mathrm{F}_{9,90}=6.09, \mathrm{P}=0.046\right)$. PTM was found lying eggs other than eye area in only four genotypes (CIP 393385.39, CIP 395112.32, PRP 0165667.6, and CIP 393371.159). The least number of total eggs laid on eyes was on genotype CIP $394600.52(2.33 \pm 1.00)$ followed by variety Khumal Ujjwal $(2.33 \pm 2.45)$. The highest number of total laid eggs in both eyes, and on eyes and outside was in genotype CIP 393385.39 $(22.22 \pm 10.86$ and $23.11 \pm 10.95)$ followed by PRP $296667.2(16.33 \pm 5.43$ and $16.56 \pm 5.41)$.

\section{Damage susceptibility}

Average number of tunnel $\left(\mathrm{F}_{9}, 90=3.014, \mathrm{P}=0.004\right)$ and total tunnel length per tuber $\left(\mathrm{F}_{9,90}=\right.$ $2.94, \mathrm{P}=0.005)$ were highly significant among genotypes. Both the number of tunnels and total tunnel length made by potato tuber moth was counted and measured for ten potato genotypes. The highest number of tunnel was found in genotype PRP $296667.2(4.67 \pm 0.44)$ followed by variety Khumal Upahar (4.44 \pm 0.67$)$ and genotype CIP 393371.159. Similarly,

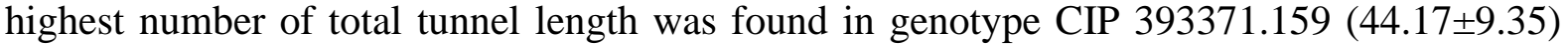
followed by PRP 296667.2 (43.79 \pm 4.72$)$ (Figure 4).

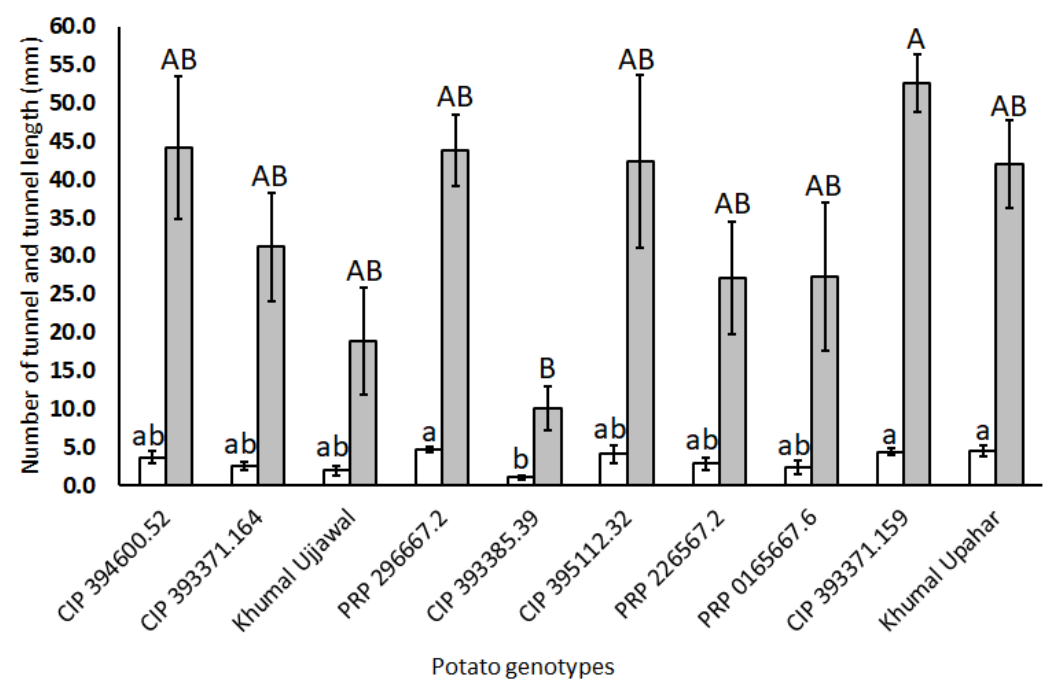

Figure 4: Number of tunnel and total tunnel length formed by PTM during its feeding inside tubers of different genotypes of potato. Grey bar indicates tunnel length while clear bar indicates number of tunnel. Letter above bars indicate mean difference with Tukey's Post hoc at 0.05 level. Bar represents standard errors $( \pm \mathrm{SE})$.

Although genotype CIP 393385.39 and Khumal Ujjwal was among the most preferred genotype for oviposition, number of tunnels and total tunnel length remained very low. This 
may be due to physical and chemical factors associated with these genotypes which allow them to be less susceptible to potato tuber moth damage.

\section{Correlation results}

The correlation of physical characteristics of potato genotypes with number of egg, number of tunnel, tunnel length in free choice condition was shown in Table 4. All the tested potato genotypes showed significance in case of correlation between number of eyes with eggs and total number of eggs. Similarly, parameter like number of tunnel and length of tunnel was significant in all tested potato tuber genotypes. Only one genotype CIP 395112.32 was highly negatively correlated with number of eyes and tunnel number. In case of correlation between egg number and eye depth, the correlation becomes insignificant for all genotypes except for CIP 393371.164 which was significant.

Table 4: Correlation of different variables of potato genotypes with number of egg, number of tunnel, tunnel length in free choice condition

\begin{tabular}{lllllll}
\hline Variety & \multicolumn{2}{c}{$\begin{array}{c}\text { No. of eye with egg and } \\
\text { No. of total no. of egg }\end{array}$} & $\begin{array}{c}\text { No. of tunnel and length } \\
\text { of tunnel }\end{array}$ & $\begin{array}{c}\text { No. of of egg and eye } \\
\text { depth }\end{array}$ \\
\cline { 2 - 7 } & $\mathrm{r}$ & $\mathrm{p}$ & $\mathrm{r}$ & $\mathrm{p}$ & $\mathrm{r}$ & $\mathrm{p}$ \\
\hline CIP 394600.52 & $0.966 * *$ & 0.000 & $0.852^{* *}$ & 0.004 & -0.37 & 0.326 \\
CIP 393371.164 & $0.929 * *$ & 0.000 & $0.969 * *$ & 0.000 & 0.801 & $0.01 *$ \\
Khumal Ujjawal & $0.968^{* *}$ & 0.000 & $0.983 * *$ & 0.000 & 0.281 & 0.465 \\
PRP 296667.2 & $0.956^{* *}$ & 0.000 & $0.775 * *$ & 0.014 & -0.586 & 0.098 \\
CIP 393385.39 & $0.736 * *$ & 0.024 & $0.964 * *$ & 0.000 & 0.467 & 0.205 \\
CIP 395112.32 & $0.829 * *$ & 0.006 & $0.976 * *$ & 0.000 & -0.225 & 0.56 \\
PRP 226567.2 & $0.908^{* *}$ & 0.001 & $0.977 * *$ & 0.000 & -0.107 & 0.784 \\
PRP 0165667.6 & $0.907 * *$ & 0.001 & $0.996 * *$ & 0.000 & -0.004 & 0.992 \\
CIP 393371.159 & $0.917 * *$ & 0.000 & $0.858^{* *}$ & 0.003 & 0.253 & 0.511 \\
KhumalUpahar & $0.983 * *$ & 0.000 & $0.904 * *$ & 0.001 & -0.049 & 0.901 \\
Total & $0.906 * *$ & 0.000 & $0.94 * *$ & 0.000 & 0.142 & 0.182 \\
\hline
\end{tabular}

$\mathrm{r}=$ correlation coefficient, $\mathrm{p}=$ probability, $* *=$ highly significant at 0.01 level

\section{DISCUSSION}

Resistance of potato varieties to potato tuber moth have been studied which showed variable level of resistance among diferent varieties or genotypes (Gyawali, 1998; Horgan et al., 2013; Rondon et al., 2013; Sharaby et al., 2014; Upadhyaya et al., 2020b) to oviposition and larval damage. We also observed variable ovipositional preferences and damage in our tested genotypes of potato. Tuber characters such as number of eyes, eye depth, and surface area was determined so that these characters could also be associated with oviposition and tunneling preference of the insect. Egg laid on eyes of the tuber were more compared to the egg laid outside eye on skin of the potato which were also in line with the work done by Malakar and Tingey (2006) where they found that egg are laid more on eyes but PTM also lay egg on skin outside of the eye area. Fenemore (1988) reported that the depressions that can hold sufficient eggs are suitable substrate for oviposition by PTM. When potato tuber moths had choice to lay their eggs in the different varieties potato tuber genotype, CIP 393385.39 was found to have both highest number of eyes and eye depth with highest number of deposited eggs too. However the correlation analysis performed between eye 
depth and number of egg deposited to tubers of different varieties are not related except for the genotype CIP 393371.64. Malakar and Tingey (2006) found that the egg deposition and larval success are not associated with the eye bud density with their tested varieties rather the egg deposition on tuber may depend on the textures of the surface where rough or coarse (Traynier, 1975; Fenemore 1978, 1980a) surface could incite PTM to lay egg upon tubers. The tuber having fine hair like fissures also stimulates the adult PTM to deposit more eggs (Malakar \& Tingley, 2006). Das et al. (2007) further elucidated that fatty acid derivatives hydrocarbon monoterpens also play important role to stimulate male and female adult to attract for an oligophagous pest such as the potato tuber moth. Karlsson et al. (2009) showed that, Guatemalan moths have their host-finding and oviposition behaviors mediate by potato volatiles which may be present in different concentration in different genotypes (OrunaConcha et al., 2002). This was also shown by Dekebo et al. (2019b) that different varieties of tomato having different concentration of volatile have varied attraction of PTM. Thus PTM may have difference in ovipositional preferences. Therefore differential ovposition on different genotypes of potato tested must be having various reasons which need to be sorted out in future research.

The susceptibility of potato tuber varieties to infestation by the PTM depends upon epiphylaxis and endophylaxis factors of each potato variety (Sharaby et al., 2014). Fenemore (1980b) reported that the rate of damage by larvae differs according to potato varieties because the peel not only limit the larval penetration, but might create hurdle in buildup of first instar larvae inside potato tubers and their survival rate. Meisner et al. (1974) found that glutamic acid followed by valine and phenylalanine to be the major content of potato peel. Outer layer of the tubers (Periderm) also have some effects on survivability of the PTM larvae (Dogramaci \& Tingey, 2009). Horgan (2010) further illustrated that the PTM larval less penetration without entering to the deep in flesh of the tube could be due to cortex as a barrier in tubers. Number of tunnel and tunnel length are important indicator of degree of damage of potato tubers. The degree of damage differed between tested ten genotypes. Less damage due to PTM to the tuber owed to the characteristics of the firmness of the potato flesh (Mansouri et al., 2013) where penetration to the tuber having firm flesh could be hindered for neonate of PTM. In our study the variation in damage due to PTM to different genotypes may be related to the variable firmness of the tubers of different genotypes, which needs to be investigated in further study. The significant positive correlation was observed between number of tunnel and total tunnel length. Since PTM lay eggs both in eyes and skin of tubers, larvae mines tunnels regardless of number of eyes (Rondon et al., 2009). According to Malakar and Tingey (2006), no relation was observed between eye bud density and surface area of the tuber.

The glycoalkaloids, amino acids and digestible carbohydrate should be determined in the tested varieties; however they were not tested in the present study. The mechanism of resistance of varieties to potato tuber moth was most probably antibiosis (Ojero \& Mueke, 1985). Bala et al. (2018) review the nutrition basis of the insect susceptibility toward insect pests where nitrogen has positive effects on individual insect performance while carbonbased compounds have defensive mechanism against insect pests. Further potassium provides high resistance against insect-pests. High levels of potassium enhance secondary compound metabolism which reduces carbohydrate accumulation thus reducing damage from insect pests. Differences in such nutritional compound in different genotypes of potato must have been the cause of differential susceptibility of potato tuber moth. 
Raman and Palacios (1982) categorized the number of entry holes on the tuber surface as a measure of resistance. According to them one entry hole per tuber were considered highly resistant, one-two holes were considered resistant, two-four susceptible and more than four holes highly susceptible. If we consider this classification of resistance, Khumal Ujjawal and CIP 393385.39 have less than two tunnel with short tunnel length among the tested genotypes and could be regarded as resistant. Further no choice experiment should be conducted to confirm this evidence. Therefore factors such as physical, nutritional, chemical and genetical which may be involved inducing resistance mechanism should also be studied and verified. The varieties which showed less preferences for PTM to oviposit and infestation in this study should further be tested in field or utilized in breeding program.

\section{CONCLUSION}

Potato tuber moth is a serious pests of potato which cause qualitative as well as quantitative loss on tubers at stores. Major control mechanism is to use chemical pesticide but this pose great hazard risk to the growers and consumers. Therefore this study investigatd the ovipostional preferences and damage potential of potato tuber moth to tubers of different potato genotypes. The least number of total eggs laid on eyes was on genotype CIP 394600.52 followed by variety Khumal Ujjwal. The highest number of total laid eggs in both eyes, and on eyes and outside was in genotype CIP 393385.39 followed by PRP 296667.2. Khumal Ujjawal and CIP 393385.39 have less than two tunnel with short tunnel length among the tested genotypes and could be regarded as resistant. Various factors such as physical, nutritional, chemical and genetical, which may be responsible for the induced restistance should further be investigated. The genotypes should be tested in field or utilized in breeding programs.

\section{Acknowledgements}

This research is funded and supported by Nepal Agriculture Research Council NARC. Authors are thankful to Dr. Prem Nidhi Sharma, Chief of National Entomology Research Center (NERC), Khumaltar, Lalitpur and colleagues for their continuous support for this research work.

\section{Authors' Contributions}

S. Aryal designed the research plan, conducted experiment and prepared manuscript. R. Simkhada helped conduct the experiment, data recording and prepare manuscript.

\section{Conflict of Interest}

The authors declare that there is no conflict of interest with present publication.

\section{REFERENCES}

Alvarez, J. M., Dotseth, E., \& Nolte, P. (2005). Potato tuberworm a threat for Idaho potatoes. University of Idaho Extension, Idaho Agricultural Experiment Station, Moscow, ID. Retrieved from http://entnemdept.ufl.edu/creatures/veg/potato/potato_tuberworm.htm Arnone, S., Musmeci S., Bacchetta L, Cordischi N., Pucci E., Cristofaro, M., \& Sonnino, A. (1998) . Research in Solanum spp. as sources of resistance to the potato tuber moth Phthorimaea operculella (Zeller). Potato Research, 41, 39-49.

DOI: https://doi.org/10.1007/BF02360260 
Aryal, S., \& Jung, C. (2015). A Review on the Ecological Characteristics of Potato Tuber Moth, Phthorimaea operculella (Zeller) (Lepidoptera: Gelechiidae). Korean Journal of Soil Zoology, 19, 35-41.

Aryal, S., \& Jung, C. (2018). Cold tolerance characteristics of Korean population of potato tuber moth, Phthorimaea operculella (Zeller), (Lepidoptera: Gelechiidae). Entomological Research, 48, 300-307. https://doi.org/10.1111/1748-5967.12297

Aryal, S., \& Jung, C. (2019). A potential threat to tomato, a congener crop to potato from invaded potato tuber moth, Phthorimaea operculella (Zeller). Journal of Asia-Pacific Entomology, 22, 77-82. DOI: https://doi.org/10.1016/j.aspen.2018.12.008

Bala, K., Sood, A.K., Pathania, V.S., \& Thakur, S. (2018). Effect of plant nutrition in insect pest management: A review. Journal of Pharmacognosy and Phytochemistry, 7(4), 2737-2742

CIP. (1988). Integrated insect pest management for potatoes in developing countries. CIP (International Potato Center, Lima, Peru). Circular, 16, 1-8

Das, G.P., \& Raman, K.V. (1994). Alternate hosts of the potato tuber moth, Phthorimaea operculella (Zeller). Crop Protection, 13, 83-86. https://doi.org/10.1016/02612194(94)90155-4

Dekebo, A., Aryal, S., \& Jung, C. (2019a). Suitability of tomato leaves for larval development of Potato Tuber Moth, Phthorimaea operculella (Zeller) (Lepidoptera: Gelechiidae). Entomological Research, 49, 258-264. https://doi.org/10.1111/17485967.12360

Dekebo, A., Aryal, S., \& Jung, C. (2019b). Olfactory responses of adult Potato Tuber Moth, Phthorimaea operculella (Zeller) measured by attraction relative to the tomato leaf volatiles. Journal of Asia-Pacific Entomology. https://doi:10.1016/j.aspen.2019.04.007

Dogramaci, M., \& Tingey, W.M. (2008). Host resistance and influence of tuber surface on larval performance of potato tuberworm (Lepidoptera: Gelechiidae). Journal of Pest Science, 82(2), 109-114. DOI: https://doi:10.1007/s10340-008-0228-7

Fenemore. P.G. (1978). Oviposition of potato tuber moth, Phthorimaea operculella Zell. Lepidoptera: Gelechildae); the physical nature of the oviposition substrate. New Zealand Journal Zoology, 591-599. DOI: https://doi.org/10.1016/00221910(88)90047-9

Fenemore. P. G. (1980a). Oviposition of potato tuber moth, Phthorimaea operculella Zell. (Lepidoptera: Gelechiidae); identification of host-plant factors influencing oviposition response. New Zealand Journal Zoology. 7, 435439. DOI: http://dx.doi.org/10.1080/03014223.1980.10423798

Fenemore. P.G. (1980b). Susceptibility of potato cultivars to potato tuber moth, Phthorimaea operculella Zell. (Lepidoptera:Gelechiidae). New Zealand Journal of Agricultural Research, 23, 539-546. DOI: https://doi.org/10.1080/00288233.1980.10417881

Fenemore. P. G. (1988). Host-plant location and selection by adult potato moth, Phthormaea operculella (Lepidoptera: Gelechiidae): A Review: Journal of Insect Physiology, 34(3), 175-177.

Foot. M. A. (1976). Susceptibility of twenty potato cultivars to the potato moth (Phthorimaea operculella) at Pukekohe: A preliminary assessment. New Zealand Journal of Experimental Agriculture, 4, 239-242. https://doi.org/10.1080/03015521.1976.10425876

Gao, Y. L. (2015). Potato tuberworm: impact and methods for control - Mini Review. CAB Reviews, 13(022), 1-3. 
Retrieved from https://www.cabi.org/bni/FullTextPDF/2018/20183347372.pdf

Golizadeh, A., \& Esmaeili, N. (2012). Comparative Life History and Fecundity of Phthorimaea operculella (Lepidoptera: Gelechiidae) on Leaves and Tubers of Different Potato Cultivars. Journal of Economic Entomology, 105(5), 1809-1815. https://doi.org/10.1603/EC12144

Gurr, G.M., \& Symington, C.A. (1998). Resistance to the potato tuber moth, Phthorimaea operculella (Zeller) (Lepidopter: Gelechiidae), in potato (Solanum tuberosum ssp. tuberosum L.). Australian Journal of Entomology, 37, 4951. https://doi.org/10.1111/j.1440-6055.1998.tb01542.x

Gyawali, B.K. (1989). Ovipositional preference of tuber moth Phthorimaea (Gnorimoschema) operculella Zeller on five varieties of potatoes in Nepal. Tropical Pest Management, 35, 106-107. http://dx.doi.org/10.1080/09670878909371331

Horgan, F.G., Quiring, D.T., Lagnaoui, A., \& Pelletie, Y. (2013). Tuber production, dormancy and resistance against Phthorimaea operculella (Zeller) in wild potato species. Journal of Applied Entomology, 137, 739-750.

DOI: https://doi:10.1016/S2095-3119(19)62740-1

Horgan, F.G., Quiring, D.T., Lagnaoui, A., \& Pelletier, Y. (2009). Tradeoff between foliage and tuber resistance to Phthorimaea operculella in wild potatoes. Entomologia Experimentalis et Applicata, 131,130-137. DOI: https://doi.org/10.1111/j.15707458.2009.00842.x

Joshi, S.L. (2004). Status of potato tuber moth, Phthorimaea operculella (Zeller) (Lepidoptera: Gelechiidae) as an insect pest on potato crop and its reaction on different varieties of stored potato. Paper presented at the. Fourth National Conference on Science and Technology, 23-26 March 2004. Kathmandu, Nepal. pp. $1-5$

Joshi, S.L. (1989). Comparative life cycle of the potato tuber moth, Phthorimaea operculella (Zeller) (Lepidoptera: Gelechiidae) on potato tubers and foliages and its economic loss in yield. Journal of Entomological Society of Nepal, 1, 59-69.

Jung, J.M., Lee, S.G., Kim, K.H., Jeon, S.W., Jung, S., \& Lee, W.H. (2019). The Potential Distribution of the Potato Tuber Moth (Phthorimaea Operculella) Based on Climate and Host Availability of Potato. Agronomy 10(1),12. DOI: https:// doi:10.3390/agronomy10010012

Karki, T.B. (2002). Post-harvest technology in Nepal. Proceedings of SAARC workshop on post-harvest technology, September 24-25, Kathmandu, Nepal. Pp. 64.

Kroschel, J., \& Koch, W. (1994). Studies on the population dynamics of the potato tuber moth Phthorimaea operculella Zeller. (Lep., Gelechiidae) in the Republic of Yemen. Journal of Applied Entomology, 118, 327-341. DOI: https://doi.org/10.1111/j.14390418.1994.tb00808.x

Kroschel, J., Sporleder, M., Tonnang, H.E.Z., Juarez, H., Carhuapoma, P., Gonzales, J.C., \& Simon, R. (2013). Predicting climate-change-caused changes in global temperature on potato tuber moth Phthorimaea operculella (Zeller) distribution and abundance using phenology modeling and GIS mapping. Agricultural and Forest Meteorology,170, 228-241. DOI: https://doi.org/10.1016/j.agrformet.2012.06.017

Lange, W.H., \& Bronson, L.(1981).Insects pests of tomato. Annual Review of Entomology, 26, 345-371. DOI: https://doi.org/10.1146/annurev.en.26.010181.002021

Maharjan, R., \& Jung, C. (2011). Rearing Methods of Potato Tuber Moth, Phthorimaea operculella (Zeller) (Lepidoptera: Gelechiidae). Korean Journal of Soil Zoology, 15, 53-57 
Malakar-Kuenen, R., \& Tingey, W. M. (2006). Aspect of tuber resistance in hybrid potatoes to potato tuberworm. Entomologia Experimentalis et Applicata, 120, 131-137. DOI: https://doi: 10.1111/j.1570-7458.2006.00435.x

Meisner, J., Ascher, K.R.S., \& Lavie, D. (1974). Factors influencing the attraction to oviposition of the potato tuber moth Gnorimoscheme operculella Zell. Journal of Applied Entomology, 77, 179-189. DOI: https://doi.org/10.1111/j.14390418.1974.tb03245.x

MoALD. (2019). Statistical information on Nepalese agriculture. URL: https://www.moald.gov. np/publication/ Agriculture Statistics. Retrieved: 20-102020.

Nirula, K.K. (1960). Control of potato tuber moth. Indian Potato Journal, 2, 47-51.

Ojero, M.F.O., \& Mueke, J.M. (1985). Resistance of four potato varieties to the potato tuber moth, Phthorimaea Operculella (Zell.) in Storage. International Journal of Tropical Insect Science, 6, 205-207. https://doi.org/10.1017/S1742758400006640

Oruna-Concha, M.J., Bakker, J., \& Ames, J.M. (2002). Comparison of the Volatile Components of Eight Cultivars of Potato after Microwave Baking. LWT - Food Science and Technology, 35(1), 80-86. https://doi.org/10.1006/fstl.2001.0819

Prasad, S., Mishra, B., Gupta, V., \& Rai, K.K. (1989). Extent of losses due to post harvest fungal diseases of potato. Journal of Research, Birsa Agricultural University, 1-2, 173-174.

Raman, K.V., \& Palacios, M. (1982). Screening Potato for Resistance to Potato Tuberworm. Journal of Economic Entomology, 75, 47-49.

DOI: https://doi.org/10.1093/jee/75.1.47

Rondon, S. I., Brown, C. R., \& Marchosky, R., (2013). Screening for Resistance of Potato Lines to the Potato Tuberworm, Phthorimaea operculella (Zeller) (Lepidoptera:Gelechiidae). American Journal of Potato Research, 90, 71-82.

DOI: https://doi:10.1007/s12230-012-9278-8

Rondon, S.I., Hane, D.C., Brown, C.R., Vales, M.I., \& Dogramaci, M. (2009). Resistance of potato germplasm to the potato tuberworm (Lepidoptera: Gelechiidae). Journal of Economic Entomology,102, 1649-1653

Rondon, S. I., \& Gao, Y. (2018). The Journey of the Potato Tuberworm around the World. In: FK Perveen (ed) Moths - Pests of Potato, Maize and Sugar Beet. Intech Open. DOI: http://dx.doi.org/10.5772/intechopen.81934

Satter, M.A., Sheel, S., and Kabir, M.H. (2002). Status of post-harvest technology of food crops in Bangladesh. Proceedings of SAARC workshop on post-harvest technology, September 24-25, Kathmandu, Nepal. Pp. 15-43.

Sharaby, A., Abdel-Rahman, H., Abdel-Aziz, S.H., \& Moawad, S. (2014).Susceptibility of Different Potato Varieties to Infestation by Potato Tuber Moth and Role of the Plant Powders on their Protection. - IOSR Journal of Agriculture and Veterinary, 6(4), 7180.

Sileshi, G., \& Teriessa, J. (2001). Tuber damage by potato tuber moth, Phthorimaea operculella Zeller (Lepidoptera: Gelechiidae), in the field in eastern Ethiopia. International Journal of Pest Management, 47, 109-113. https://doi.org/10.1080/09670870151130552

Sisay, A., \& Ibrahim, A. (2012). Evaluation of Some Potential Botanicals to Control Potato Tuber Moth, (Phthorimaea operculella) under Storage Condition at Bako, Western Ethiopia. International Journal of Phytopathology, 1,14-18. DOI: 10.33687/phytopath.001.01.0011 
Sporleder, M., Kroschel, J., Quispe, M.R.G., \& Lagnaoui, A. (2004). A temperature based simulation model for the potato tuberworm, Phthorimaea operculella Zeller (Lepidoptera; Gelechiidae). Environmental Entomology, 33, 477-486. https://doi.org/10.1603/0046-225X-33.3.477

Subedi, S., Ghimire, Y.N., Gautam, S., Poudel, H.K., \& Shrestha, J. (2019). Economics of potato (Solanum tuberosum L.) production in terai region of Nepal. Archives of Agriculture and Environmental Science,4(1), 57-62.

DOI: https://dx.doi.org/10.26832/24566632.2019.040109

Tiwari, D.B., Thapa, R.B., Shrestha, S.M. \& Joshi, S.L. (2006). Field survey and monitoring of potato tuber moth, Phthorimaea operculella (Zeller) (Lepidoptera: Gelechiidae). Journal of Institute of Agricultural and Animal Science, 26, 157-160.

DOI: https://doi.org/10.3126/jiaas.v27i0.710

Traynier, R. M. (1975). Field and laboratory experiments on the site of oviposition by the potato moth. Bulletin of Entomological Research, 65, 391-398.

DOI: https://doi.org/10.1017/S0007485300006064

Upadhyay, K.P., Dhami, N.B., Sharma, P.N., Neupane, J.D., \& Shrestha, J. (2020a). Growth and yield responses of potato (Solanum tuberosum L.) to biochar. Agrarian Science, 31 (2): In Press. doi: 10.15159/jas.20.18.

Upadhyay, K. P., Paudel, N., Aryal, S. Simkhada, R., Bhusal, B., \& Gautam, I. P. (2020b). Storability of potato varieties under ordinary storage condition in Panauti, Nepal. Sustainability in Food and Agriculture, 1(2), 51-57.

DOI: http://doi.org/10.26480/sfna.02.2020.88.94 